\title{
Regular Blood Donations can Help to Boost Immunity Against SARS-CoV-2 Virus?
}

\section{Ramune Sepetiene ${ }^{1 *}$, Mohamed $\mathrm{Ali}^{2}$ and Alexander Carterson ${ }^{3}$}

${ }^{1}$ Abbott GmbH, Wiesbaden, Germany

${ }^{2}$ Abbott Laboratories GmbH, DAFZA, Dubai, UAE

${ }^{3}$ Abbott Laboratories, USA

*Corresponding Author: Ramune Sepetiene, Abbott GmbH, Wiesbaden, Germany.
Received: December 10, 2021

Published: December 22, 2021

(C) All rights are reserved by Ramune

Sepetiene., et al.
The world is counting on the consequences of the Covid 19 pandemic, which has claimed millions of lives in the last couple of years, while scientists are still looking for answers how to stop the virus spreading, what methods to use to finally feel safe [1]. As the pace and requirements of vaccination accelerate, there is a segregation and resistance among people. It is clear that the current situation, the ineffectiveness of vaccination and the kaleidoscope of different opinions are unsatisfactory. While scientific studies are underway, various solutions are being done, recommendations are being made to manage and eventually stop this pandemic, we can already make some insights and offer rational solutions and issues using our own capabilities by blood donations perspective.

The scientists investigating the spreading of the virus, already found interesting dependencies among different samples of population and their response to the infection. Usually, blood donors' samples are very often use to investigate the research hypothesis and outcomes due to very well-organized questioning process and all subsequent standardized procedures. The SARS-CoV-2 virus pandemic investigation isn't an exemption.

Pandey and colleagues investigated 1191 Indian blood donors' population for SARS-CoV-2 antibodies with overall low $9.5 \%$ seropositivity, while another statistically significant difference was observed ( $p=0.003$ ) in seropositivity between voluntary and replacement blood donors' groups [2].

Another study recently published by dr. Raouf and colleagues from Dubai Blood Donation center suggests that the higher seroprevalence of SARS-CoV-2 antibody was seen more in first time donors while the regular blood donors are safer with statistical effect of $\mathrm{p}<0.001$ and more of them refer to be asymptomatic cases [3].

The study from Milan, Italy, was conducted in 2020 [4]. Authors investigated the seroprevalence trends in a random healthy blood donors' sample during the first pandemic outbreak. Their conclusions stated the SARS-CoV-2 infection circulating times and antibodies IgM/IgG reactivity with $2.4-9.0 \%$ prevalence within blood donors obtained with tests by lateral membrane immunoassay against the Nucleocapsid protein. The other valuable correlations, for instance, they detected hypertriglyceridemia has been associated with inflammation in patients with COVID-19 and severe infection is found to be associated with a decrease in circulating lymphocytes and eosinophils. Discussing the results, authors also claimed the blood donors are healthier than the general population [4].

Various effects on immunity system and stem cell mobilization or stimulation due to blood loose, various bleeding is known by science and are used to develop further treatment and diagnostic methods obtaining more information from pathogenetic mechanisms [5-7]. The known path how the elements of immunological memory are induced to protect the host organism against infection by the influenza virus [8] or various different infectious diseases and autoimmunity discrepancies $[9,10]$. Widely discussing protection possibilities evidence against Covid-19 with boosting of immunity capability by vitamin D, Vitamin C and Selenium supplements [11].

Definitely, the search of evidence helps further understanding how the SARS-CoV-2 infection works on human immunity. We still have more questions than answers. Multisite investigations how 
blood donors are affected with SARS-CoV-2 and what conclusions could be made are very welcome. Now we have the data already published that shows predisposition factors role of $\mathrm{ABO}$ blood group and SARS-CoV-2 infectivity with protective effect of $\mathrm{O}$ blood group and opposite-with group A [12]. These findings may contribute suggestions of different $\mathrm{ABO}$ blood type may have effect on different immunity response pathways.

The proven hypothesis standing for regular blood donations as immunity booster and antiviral protector could initiate subsequent research studies with global scientific impact.

\section{Bibliography}

1. Lopez-Leon S., et al. "More than 50 long-term effects of COVID-19: a systematic review and meta-analysis". Scientific Reports 11.16144 (2021).

2. Pandey HC., et al. "Seroprevalence of SARS-Coronavirus 2 among asymptomatic healthy blood donors from healthcare and non-healthcare settings: Implications for safety of blood donors and blood collection staff during blood donation". Transfusion and Apheresis Science 60.3 (2021): 103118.

3. Raouf M., et al. "Seroprevalence of IgG Anti-SARS-CoV-2 among Voluntary Blood Donors in Dubai: Demographic and Risk Factors". Dubai Medical Journal 4 (2021): 204-211.

4. Valenti L., et al. "SARS-CoV-2 seroprevalence trends in healthy blood donors during the COVID-19 outbreak in Milan". Blood Transfusion = Trasfusione Del Sangue 19.3 (2021): 181-189.

5. Sanjuan-Pla A., et al. "Platelet-biased stem cells reside at the apex of the haematopoietic stem-cell hierarchy". Nature 502.7470 (2013): 232-236.

6. Ozkan MC., et al. "Peripheral blood stem cell mobilization from healthy donors". Transfusion and Apheresis Science 53.1 (2015): 13-16.

7. Cheshier SH., et al. "The effect of bleeding on hematopoietic stem cell cycling and self-renewal". Stem Cells and Development 16.5 (2007): 707-717.

8. Wierzbicka-Woś A., et al. Układ odpornościowy a wirus grypy "[Immune system and influenza virus]". Postępy Higieny i Medycyny Doświadczalnej 69 (2015): 214-220.
9. Osei-Owusu P., et al. "FPR1 is the plague receptor on host immune cells". Nature 574.7776 (2019): 57-62.

10. Molodtsov A and Turk MJ. "Tissue Resident CD8 Memory T Cell Responses in Cancer and Autoimmunity". Frontiers in Immunology 9 (2018): 2810.

11. Bae M and Kim H. "Mini-Review on the Roles of Vitamin C, Vitamin D, and Selenium in the Immune System against COVID-19". Molecules 25.22 (2020): 5346.

12. Goel R., et al. ISBT COVID-19 Working Group. "ABO blood group and COVID-19: a review on behalf of the ISBT COVID-19 Working Group". Vox Sanguinis 116.8 (2021): 849-861.

\section{Assets from publication with us}

- Prompt Acknowledgement after receiving the article

- Thorough Double blinded peer review

- Rapid Publication

- Issue of Publication Certificate

- High visibility of your Published work

Website: www.actascientific.com/

Submit Article: www.actascientific.com/submission.php

Email us: editor@actascientific.com

Contact us: +919182824667 